\title{
An automated method for serum bilirubin determination
}

\author{
N. A. SIMMONS ${ }^{1}$ \\ From the Department of Clinical Pathology, Guy's Hospital, London
}

SYNOPSIS A method for the determination of both direct and indirect serum bilirubin on the AutoAnalyzer is described which has a number of advantages over the automated method that is currently recommended. It gives total bilirubin results which are similar to those obtained with the equivalent manual method and direct bilirubin results which are usually about $10 \%$ lower.

The effect of haemolysis on estimations was investigated. It has little influence on the total, but significantly lowers the direct bilirubin results.

Simple methods for the preparation of true bilirubin standards and a stable control serum are described.

In a very careful study Nosslin (1960) showed that the method of Jendrassik and Grof (1938) for the estimation of total serum bilirubin had many advantages over other methods and that a modification of it gave a direct reaction which was the best available index of conjugated bilirubin in the serum.

In the total bilirubin method the serum was mixed with a buffered caffeine solution which acted as an accelerator and then with diazo reagent. The azo pigment formed was converted from red to blue by the addition of alkali. In the direct reaction the accelerator solution was replaced by water and the diazo reaction terminated by ascorbic acid before treatment with alkali. Serum blanks were prepared with diazo I instead of mixed diazo reagent. The methods currently recommended for the determination of bilirubin on the Technicon AutoAnalyzer (Gambino and Schreiber, 1964) are based on these procedures.

Michaëlsson (1961) demonstrated a number of disadvantages in Nosslin's method. First, caffeine was found to reduce the optical density of alkaline azobilirubin solutions. Since it was used in the total bilirubin, but not direct bilirubin estimations, and since the amount of direct-reacting bilirubin was calculated from data obtained by putting standards through the total bilirubin procedure this could cause misleading results. Secondly, ascorbic acid and diazo reagent react to form a coloured product in the direct reaction. They were not present in the blanks

\footnotetext{
'Present address: Department of Pathology, Chase Farm Hospital, Enfield, Middlesex.
}

Received for publication 21 August 1967. for which values were consequently low. Thirdly, haemolysis reduced the values for total bilirubin.

Nosslin (1960) did not use ascorbic acid in the total bilirubin procedure. Michaëlsson (1961) showed that its inclusion minimized the effect of haemolysis. He went on to show that the other disadvantages could be overcome if all three reagents, ascorbic acid, diazo reagent, and accelerator, were all included in all three estimations, total bilirubin, direct bilirubin, and blanks. By varying the order in which the reagents were used he devised a method in which this was done and the automated method described in this paper is based on it. In addition, simple and convenient methods for the preparation of bilirubin standards and control serum are described here and the effect of haemolysis upon direct and total bilirubin determinations is investigated.

\section{METHOD}

PRINCIPLE In the determination of total bilirubin the serum is added to a caffeine reagent, which acts as an accelerator, and then mixed with combined diazo reagent. The diazo reaction is terminated by the addition of ascorbic acid which destroys the excess diazo reagent, the azobilirubin is made alkaline by the addition of a tartrate buffer, and the intensity of the colour read at $600 \mathrm{~m} \mu$.

To determine the direct-reacting bilirubin the serum is mixed with water and diazo reagent. The reaction is terminated by ascorbic acid and then caffeine is added. Again the azobilirubin is made alkaline with tartrate buffer.

When blanks are run the serum is mixed with water and ascorbic acid. Diazo reagent, caffeine, and tartrate reagent are added subsequently. 
REAGENTS The following are required:

Ascorbic acid A $0.8 \%$ solution is made up each day by dissolving $400 \mathrm{mg}$ in $50 \mathrm{ml}$ distilled water. (This was found to be sufficient for total and direct bilirubin determinations on at least 20 specimens.)

Caffeine mixture Hydrated sodium acetate, $84 \mathrm{~g}$, $50 \mathrm{~g}$ sodium benzoate, and $33 \mathrm{~g}$ caffeine are dissolved in approximately $800 \mathrm{ml}$ distilled water at $50^{\circ}$ to $60^{\circ} \mathrm{C}$. This is made up to $1,000 \mathrm{ml}$ when cool.

Diazo I solution Sulphanilic acid, $5.0 \mathrm{~g}$, is dissolved in distilled water containing $15 \mathrm{ml}$ concentrated hydrochloric acid (specific gravity $1 \cdot 19$ ) and the volume made up to $1,000 \mathrm{ml}$.

Diazo II solution Sodium nitrite, $0.5 \%$ in distilled water, is stored in a dark bottle and renewed every 14 days.

Diazo reagent Diazo $\mathrm{II}, 1.25 \mathrm{ml}$, is added to $50 \mathrm{ml}$ diazo I. This is stable for 24 hours (Gambino and Schreiber, 1964) and is made up each day.

Alkaline reagent (2 strength Fehling's II solution) Sodium hydroxide, $66 \mathrm{~g}$, and $217 \mathrm{~g}$ sodium potassium tartrate are dissolved in distilled water and the volume made up to $1,000 \mathrm{ml}$.

Distilled water BRIJ-35 (Technicon), $0.5 \mathrm{ml}$, may be added to each litre if it is to be run through the manifold.

STANDARDS The method for their preparation is a modification of that described by Gadd (1966). A $5 \%$ solution

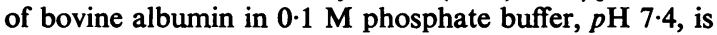
prepared. It is stored in the refrigerator. The buffer is made by dissolving $13.97 \mathrm{~g}$ anhydrous dipotassium hydrogen phosphate and $2.69 \mathrm{~g}$ anhydrous potassium dihydrogen phosphate in distilled water and making the volume up to $1,000 \mathrm{ml}$.

Bilirubin (molar absorptivity 60,700 \pm 800 , British Drug Houses Ltd), $50 \mathrm{mg}$ is dissolved in $50 \mathrm{ml}$ dimethylsulphoxide. Without delay $7.5 \mathrm{ml}$ of this solution is made up to $50 \mathrm{ml}$ and $10 \mathrm{ml}$ made up to $100 \mathrm{ml}$ with the albumin solution. These standards contain $15 \mathrm{mg}$ and $10 \mathrm{mg}$ bilirubin per $100 \mathrm{ml}$ respectively. Standards containing $5.0,2.5,1.25$, and $0.6 \mathrm{mg}$ per $100 \mathrm{ml}$ of albumin solution are prepared from the $10 \mathrm{mg}$ per $100 \mathrm{ml}$ standard.

At the same time as the standards are prepared, the concentration of bilirubin is checked spectrophotometrically as follows: $1.0 \mathrm{ml}$ of the solution of $50 \mathrm{mg}$ bilirubin in $50 \mathrm{ml}$ dimethylsulphoxide is added to $9.0 \mathrm{ml}$ dimethylsulphoxide and $0.2 \mathrm{ml}$ of this solution added to a further $3.8 \mathrm{ml}$ dimethylsulphoxide (total dilution 1:200). The optical density of this solution at $453 \mathrm{~m} \mu$ is read in a $1 \mathrm{~cm}$ cuvette against a blank of dimethylsulphoxide. The optical density is multiplied by $19 \cdot 26$ (based on a molar absorptivity of 60,700 ) to give the concentration of bilirubin in the standard expected to contain $10 \mathrm{mg}$ per $100 \mathrm{ml}$. The molar absorptivity was confirmed by observation.

This method differs slightly from that of Gadd (1966). To check the bilirubin concentration spectrophotometrically he used a dilution in dimethylsulphoxide of the $10 \mathrm{mg}$ per $100 \mathrm{ml}$ standard which contains albumin, whereas the solution used to check the concentration in this method contains none. His method was found to be unsatisfactory, for the small amount of albumin in the $10 \mathrm{mg}$ standard increased the optical density of the bili-

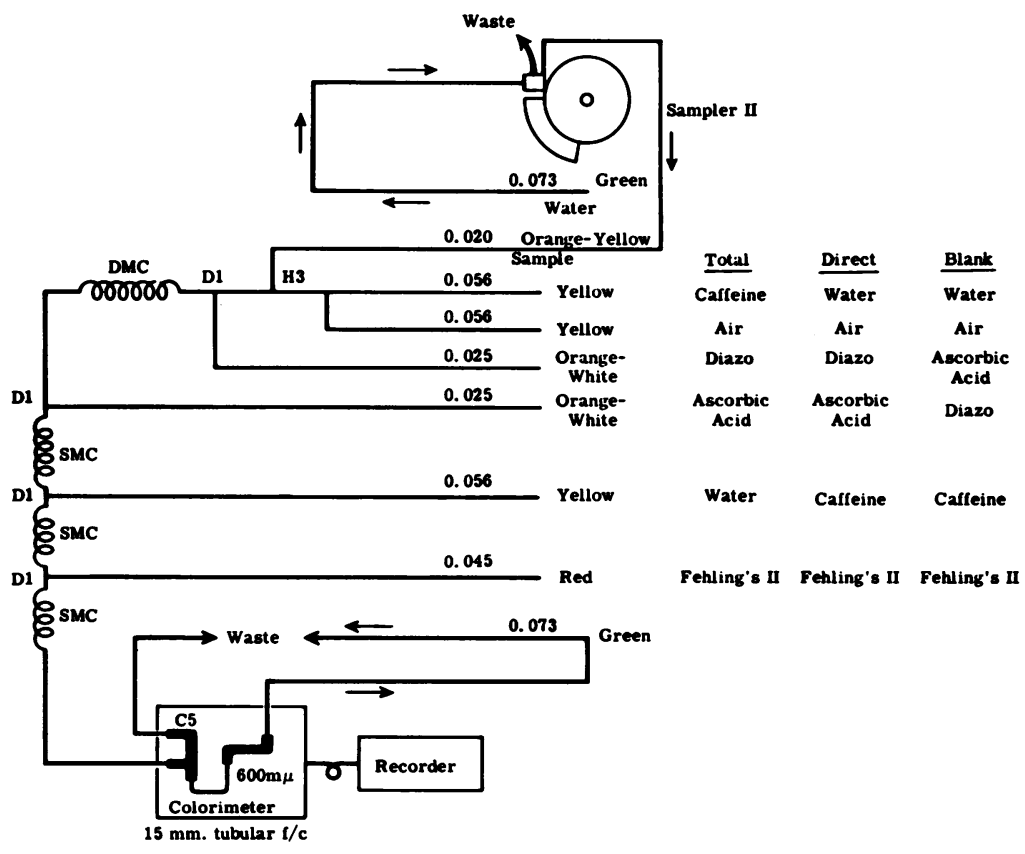

FIG. 1. Diagram of manifold for bilirubin estimations. 
rubin solutions and changed the peak of the bilirubin absorption curve from $453 \mathrm{~m} \mu$ to $458 \mathrm{~m} \mu$.

Standards are dispensed into small quantities and stored in the dark at $-20^{\circ} \mathrm{C}$. They are stable for at least 30 days.

CONTROL SERUM This is prepared from discarded blood removed at exchange transfusion from babies with haemolytic disease of the newborn who have a preexchange serum bilirubin greater than $10 \mathrm{mg}$ per $100 \mathrm{ml}$. Blood diluted with heparinized saline during the exchange transfusion is suitable. Plasma is separated by centrifugation from approximately $500 \mathrm{ml}$. To render it clear and free from clots it is first stored at $4^{\circ} \mathrm{C}$ for three days. Large clots are removed and it is transferred to a deep freeze at $-20^{\circ} \mathrm{C}$. After 24 hours it is thawed, centrifuged, and the supernatant cleared by passing it through a sintered glass filter ('grade 3'). The value for the bilirubin concentration is determined by repeated estimations using commercial serum as a control. The material is dispensed into small quantities and stored in the dark at $-20^{\circ} \mathrm{C}$. It is stable for at least 10 months.

OPERATING PROCEDURE Samples are analysed at a rate of up to 70 per hour. The sample line aspirates $0.16 \mathrm{ml}$ per min, therefore about $0.1 \mathrm{ml}$ of sample is aspirated for each of the three runs, total and direct bilirubin and blank. For specimens containing more than $15 \mathrm{mg}$ bilirubin per $100 \mathrm{ml}$ the serum is diluted $1: 3$ with distilled water. It is usually easy to see with the naked eye specimens containing more than $2 \mathrm{mg}$ per $100 \mathrm{ml}$, and to avoid carry-over these can be placed at the end of the run or followed by a

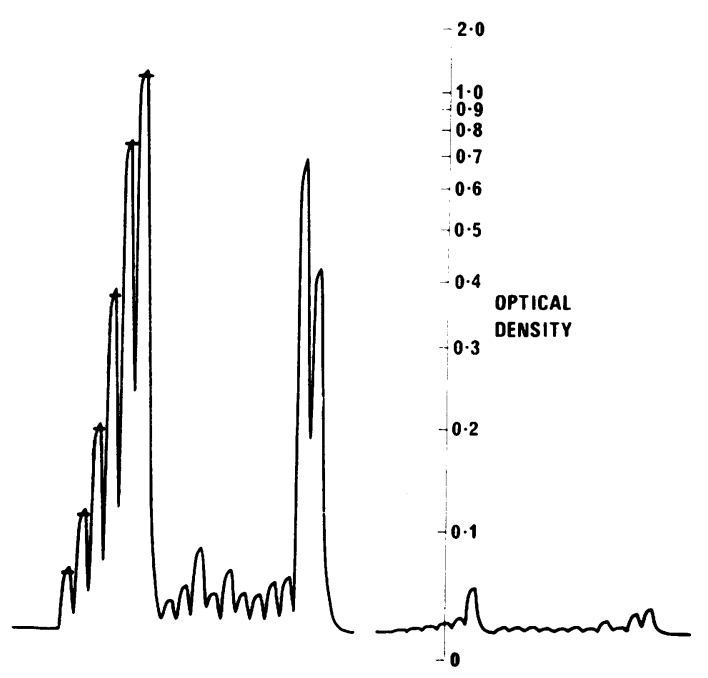

FIG. 2. Auto Analyzer record of bilirubin estimations. Six standards from 0.6 to $15 \mathrm{mg}$ per $100 \mathrm{ml}$ are followed by 11 sera. The first half of the record is of total bilirubin, the second half of blanks. Horizontal lines near the top of the standards' peaks indicate their corrected values. sample cup containing distilled water. A $15 \mathrm{~mm}$ tubular flowcell and $600 \mathrm{~m} \mu$ filters are used. A recorder chart speed of 18 inches per hour is suitable and chart paper calibrated to show optical density is used. Reagents are aspirated in a different order for the estimation of total and direct bilirubin and blanks (Fig. 1). Changing the order is simplified by mounting the manifold on a platter and numbering the lines. Between each different type of estimation water is washed through the manifold rapidly for about a minute. Although blanks usually give low values, this is not so if the samples are cloudy or haemolysed and for accurate results they should be run routinely.

To read the results the optical density of the standards' blanks is subtracted from the optical density when their total bilirubin is estimated and a horizontal line is drawn near the top of their peaks to show the corrected value (Fig. 2). These points are used to draw the standard curve on the chart reader and this is used to read the total and direct bilirubin of the samples and their blanks. The figures obtained for the total and direct bilirubins of the samples are corrected by subtracting from them the values obtained for the blanks.

\section{RESULTS}

Unless stated otherwise tests were performed on plasma from heparinized blood.

ACCURACY AND REPRODUCIBILITY Twenty-five total bilirubin determinations were performed on different days on a control serum prepared in the laboratory by the method described above. The mean concentration was $7.3 \mathrm{mg}$ per $100 \mathrm{ml}$, the standard deviation $0.27 \mathrm{mg}$ per $100 \mathrm{ml}$, and the coefficient of variation $3.7 \%$.

Estimations of the total bilirubin content of four commercial control sera were made. Each serum was put through six consecutive times in a single run. Individual values obtained with each serum varied from the mean by less than $2 \%$. The mean values were close to those given by the manufacturer (Table I).

TABLE I

RESULTS OF DETERMINATIONS ON COMMERCIAL CONTROL SERA

\begin{tabular}{llll}
$\begin{array}{l}\text { Serum } \\
\text { No. }\end{array}$ & Manufacturer's Method & \multicolumn{2}{l}{ Total Bilirubin $(\mathrm{mg} / 100 \mathrm{ml})$} \\
\cline { 3 - 4 } & & $\begin{array}{l}\text { Manufacturer's } \\
\text { Value }\end{array}$ & $\begin{array}{l}\text { Determined } \\
\text { Value }\end{array}$ \\
\hline I & Weight & 0.65 & 0.7 \\
II & King and Wootton (1956) & $2 \cdot 8$ & $2 \cdot 5$ \\
III & Weight & $5 \cdot 0$ & 4.9 \\
IV & Malloy and Evelyn (1937) & $7 \cdot 1$ & 7.4
\end{tabular}

Six consecutive determinations of direct bilirubin were performed in one run on a specimen known to have a high value. Individual values varie $\mathrm{J}$ from the mean of $7.7 \mathrm{mg}$ per $100 \mathrm{ml}$ by less than $1 \%$. 
RECOVERY Determinations of total bilirubin were made on pooled human serum whose initial bilirubin concentration was known and to which bilirubin in $5 \%$ bovine albumin had been added. Recoveries varied between 95 and $102 \%$ (Table II).

TABLE II

\section{RECOVERY EXPERIMENT}

\begin{tabular}{llllr}
$\begin{array}{l}\text { Bilirubin } \\
\text { Added } \\
(\mathrm{mg} / 100 \mathrm{ml})\end{array}$ & $\begin{array}{l}\text { Theoretical } \\
\text { Value } \\
(\mathrm{mg} / 100 \mathrm{ml})\end{array}$ & $\begin{array}{l}\text { Determined } \\
\text { Value } \\
(\mathrm{mg} / 100 \mathrm{ml})\end{array}$ & $\begin{array}{l}\text { Bilirubin } \\
\text { Recovered } \\
(\mathrm{mg} / 100 \mathrm{ml})\end{array}$ & $\begin{array}{l}\text { Percentage } \\
\text { Recovery }\end{array}$ \\
\hline 1.0 & $1 \cdot 15$ & 1.1 & 0.95 & 95 \\
2.5 & 2.65 & 2.7 & 2.55 & 102 \\
5.0 & 5.15 & 5.0 & 4.85 & 97
\end{tabular}

COMPARISON WITH A MANUAL METHOD The manual method employed was in routine use at Guy's Hospital and differed from the method recommended by Michaëlsson (1961) only in that a caffeine solution was used as the accelerator instead of a diphylline mixture. Total bilirubin determinations were performed on 103 specimens and direct bilirubin determinations on 100 specimens by the manual and automated methods.

Fifty-six specimens were found to have a total bilirubin concentration of more than $0.5 \mathrm{mg}$ per $100 \mathrm{ml}$ by both methods and these results are plotted on a scattergram (Fig. 3) which shows that the two methods gave similar results. With values between 1.0 and $2.0 \mathrm{mg}$ per $100 \mathrm{ml}$, the two methods occasion-

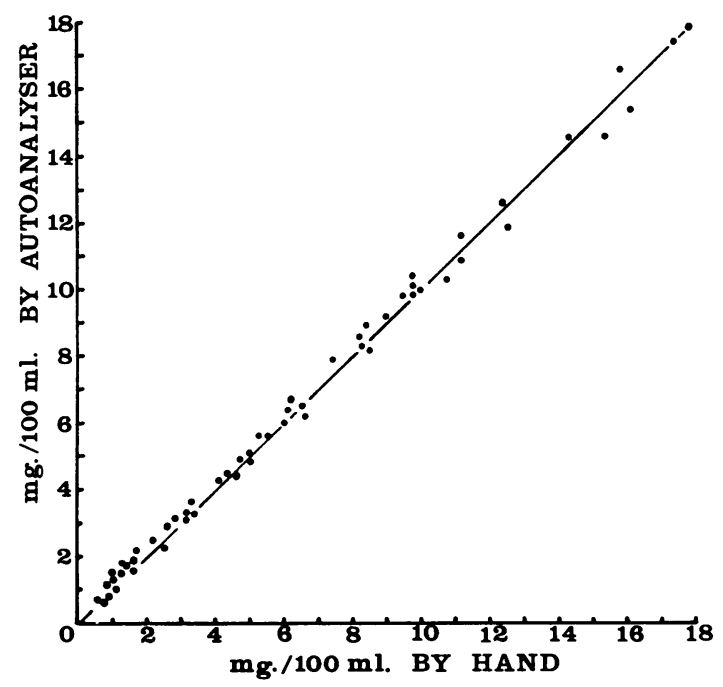

FIG. 3. Comparison between 56 total bilirubin results obtained with the AutoAnalyzer and the manual method. The solid line indicates complete agreement between the two methods.

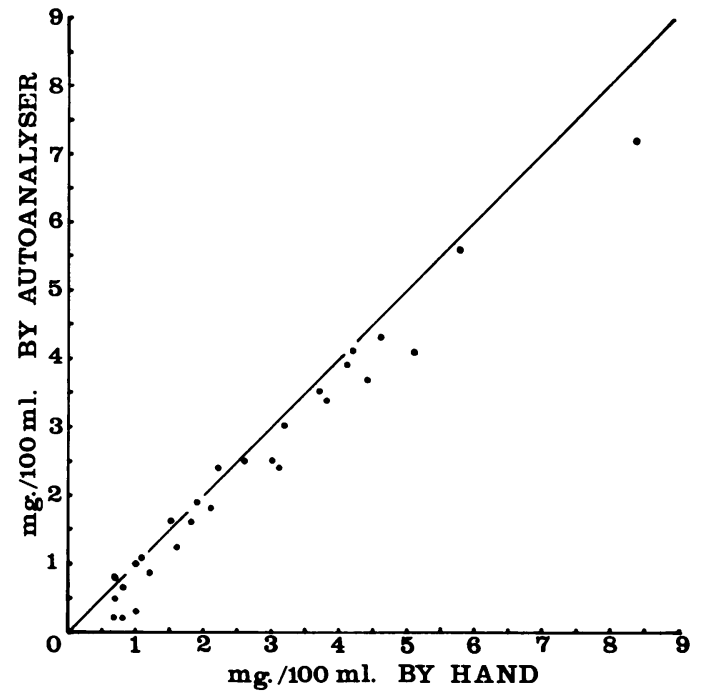

FIG. 4. Comparison between 28 direct-reacting bilirubin results obtained with the AutoAnalyzer and the manual method.

ally differed by up to $0.4 \mathrm{mg}$ per $100 \mathrm{ml}$, but the results of manual estimations in this range performed by different workers on the same specimen occasionally differed from each other by the same amount; repeated automated determinations in this range varied by no more than $0.1 \mathrm{mg}$ per $100 \mathrm{ml}$. Fortyseven specimens were found to have a total bilirubin concentration of $0.5 \mathrm{mg}$ or less per $100 \mathrm{ml}$. In 37 of these the results obtained with the two methods differed by no more than $0.1 \mathrm{mg}$ per $100 \mathrm{ml}$. In nine they differed by $0.2 \mathrm{mg}$ and in one by $0.3 \mathrm{mg}$ per $100 \mathrm{ml}$.

Twenty-eight specimens were found to have a direct reacting bilirubin of more than $0.5 \mathrm{mg}$ per $100 \mathrm{ml}$ by both methods and these results are shown in Figure 4. In this range the automated method tended to give values approximately $10 \%$ lower than the manual method.

Seventy-two specimens were found to have a direct reacting bilirubin of $0.5 \mathrm{mg}$ or less per $100 \mathrm{ml}$. In 54 of these results obtained with the two methods differed by no more than $0.1 \mathrm{mg}$ per $100 \mathrm{ml}$. In 14 they differed by $0.2 \mathrm{mg}$ and in four by $0.3 \mathrm{mg}$ per $100 \mathrm{ml}$.

NORMAL RANGE The total and direct reacting bilirubin concentrations were determined in 100 specimens from blood donors. Figure 5 shows the distribution of the total bilirubin results. In 95 specimens the concentration was between $0.2 \mathrm{mg}$ and $0.8 \mathrm{mg}$ per $100 \mathrm{ml}$. No direct reacting bilirubin was 


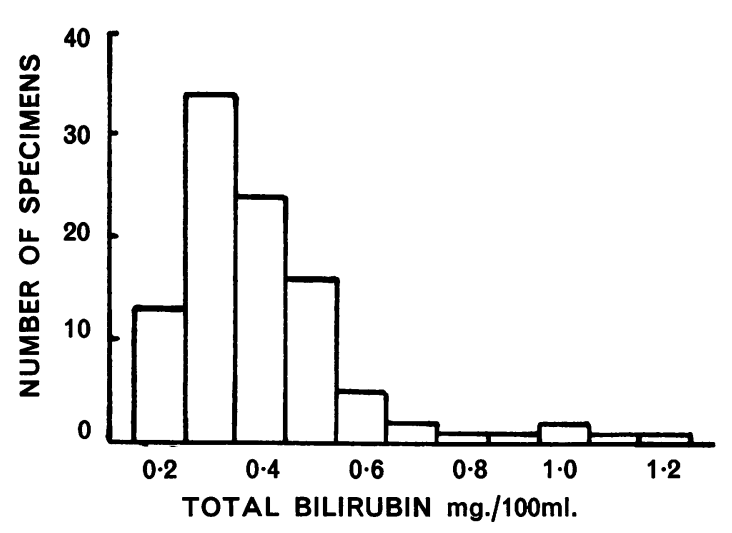

FIG. 5. Histogram of total bilirubin values determined on 100 normal sera.

detected in 44 of the specimens. In 55 of the others the concentration was found to be not higher than $0.1 \mathrm{mg}$ per $100 \mathrm{ml}$. In one specimen it was $0.2 \mathrm{mg}$ per $100 \mathrm{ml}$.

\section{THE EFFECT OF ADDED HAEMOLYSED BLOOD}

A solution containing $10 \mathrm{~g}$ haemoglobin per $100 \mathrm{ml}$, prepared from pooled human erythrocytes lysed with distilled water, was added to sera containing bilirubin to give final haemoglobin concentrations of $1.0 \mathrm{~g}$, $0.5 \mathrm{~g}$, and $0.1 \mathrm{~g}$ per $100 \mathrm{ml}$. Controls were prepared by the addition of distilled water to the sera instead of haemoglobin solution and determinations of total and direct bilirubin carried out.

Some typical results are shown in Table III.

\section{TABLE III}

EFFECT OF THE ADDITION OF LYSED RED CELLS TO A SPECIMEN CONTAINING $9.1 \mathrm{mg} / 100 \mathrm{ml}$ TOTAL BILIRUBIN AND $7.0 \mathrm{mg} /$ $100 \mathrm{ml}$ DIRECT BILIRUBIN

\begin{tabular}{|c|c|c|c|c|}
\hline \multirow{2}{*}{$\begin{array}{l}\text { Haemoglobin } \\
\text { Concentration } \\
(\mathrm{g} / 100 \mathrm{ml})\end{array}$} & \multicolumn{2}{|c|}{ Total Bilirubin } & \multicolumn{2}{|c|}{ Direct Bilirubin } \\
\hline & $\mathrm{mg} / 100 \mathrm{ml}$ & $\begin{array}{l}\text { Percentage } \\
\text { of Control }\end{array}$ & $\mathrm{mg} / 100 \mathrm{ml}$ & $\begin{array}{l}\text { Percentage } \\
\text { of Control }\end{array}$ \\
\hline $\begin{array}{l}1.0 \\
0.5 \\
0.1\end{array}$ & $\begin{array}{l}8 \cdot 3 \\
8 \cdot 7 \\
9 \cdot 0\end{array}$ & $\begin{array}{l}91 \\
96 \\
99\end{array}$ & $\begin{array}{l}1 \cdot 9 \\
3 \cdot 8 \\
6 \cdot 3\end{array}$ & $\begin{array}{l}27 \\
54 \\
90\end{array}$ \\
\hline
\end{tabular}

Addition of lysed red cells had little effect on the total bilirubin results. However, the direct-reacting bilirubin was significantly reduced and when haemoglobin was present even in the lowest concentration the results obtained were approximately $10 \%$ lower than in the control. Similar results were obtained when determinations were performed by the manual method.
When haemoglobin was present in plasma, values for the blanks were significantly increased and their routine inclusion was essential since small amounts of haemoglobin were difficult to detect when the bilirubin level was raised.

\section{DISCUSSION}

The manual method of Jendrassik and Grof (1938) for the determination of total bilirubin is usually regarded as the best available (With, 1954). Nosslin (1960) devised an excellent method based on it for the quantitative determination of direct-reacting bilirubin and the methods currently recommended for the determination of total and direct bilirubin on the AutoAnalyzer are based on these procedures (Gambino and Schreiber, 1964). Michaëlsson (1961) pointed out a number of disadvantages in the Nosslin-Jendrassik-Grof procedures and introduced modifications which overcame them. The automated method described in this paper is based on Michaëlsson's procedure. It gave total bilirubin results similar to those obtained with a manual method, but the direct bilirubins were usually lower. This was not unexpected for colour development in the direct diazo reaction may be rapid for an initial period of about one minute, but then continue at a slower rate for at least 45 minutes (Nosslin, 1960), and the time allowed for diazotization in the automated method is only about three minutes compared with 10 minutes in the manual method.

The amount of direct-reacting bilirubin found in normal serum by this method was small and in 99 of the 100 specimens from blood donors it was no higher than $0.1 \mathrm{mg}$ per $100 \mathrm{ml}$. However, it must be emphasized that levels slightly above this are not necessarily due to an increase in conjugated bilirubin and may simply reflect a much larger increase in total bilirubin (Nosslin, 1960).

The instability of bilirubin in strong alkali has always been a source of difficulty in the preparation of standards. Gadd (1966) found that it was more stable in dimethylsulphoxide and, slightly modified, his method of preparation was found to be satisfactory.

In automated procedures the regular use of a control serum is desirable. Commercial preparations may be used, but if they are included in each run they may prove to be expensive. The bilirubin control serum described in this paper was found to be very easy to prepare and stable for at least 10 months.

The present investigation showed that haemolysis has little effect upon the total bilirubin measured by the automated method and the results are in agreement with those of Michaëlsson (1961). However, it 
was found that the amount of direct-reacting bilirubin was significantly reduced in the presence of even small amounts of haemoglobin. Failure to recognize this fact could lead to a serious underestimation of the proportion of conjugated bilirubin in the serum.

I wish to thank Dr. J. Liddell and Mrs. C. Michael for their help and advice.
REFERENCES

Gadd, K. G. (1966). J. clin. Path., 19, 300.

Gambino, S. R., and Schreiber, H. (1964). Text as presented at the 1964 Technicon International Symposium, New York. Technicon Instruments Corporation, New York.

Jendrassik, L., and Grof, P. (1938). Biochem. Z., 297, 81.

King, E. J., and Wootton, I. D. P. (1956). Micro-analysis in Medical Biochemistry, 3rd ed. Churchill, London.

Malloy, H. T., and Evelyn, K. A. (1937). J. biol. Chem., 119, 481.

Michaëlsson, M. (1961). Scand. J. clin. Lab. Invest., 13, suppl. 56.

Nosslin, B. (1960). Ibid., 12, suppl. 49.

With, T. K. (1954). Biology of Bile Pigments. Frost-Hansen, Copenhagen.

\section{The January 1968 Issue}

\section{THE JANUARY 1968 ISSUE CONTAINS THE FOLLOWING PAPERS}

Trace metals in the brain and in Wilson's disease JoHN N. CUMINGS

Neutron activation analysis for copper in biological material applied to Wilson's disease G. S. FELL, HAMILTON SMITH, and R. A. HOWIE

Comparison between a microdiffusion and an ion exchange method for the determination of plasma ammonium J. D. ACLAND and R. STRONG

Improved method for the estimation of plasma ammonia by ion exchange J. C. B. FENTON and A. H. WILLIAMS

New aspect of hepatic nuclear glycogenosis in diabetes F. CARAMIA, F. G. GHERGO, C. BRANCIARI, and G. MENGHINI

A trial of phosphohexose isomerase as a means of detecting cervical carcinoma GRAINGER G. MUIR and GAJUTE J. VALTERIS

Alpha $_{2}$-macroglobulin levels in disease in man JAMES HOUSLEY

Primary 'acquired' hypogammaglobulinaemia and amyloidosis W. D. MURRAY and I. A. COOK

Significance for the diagnosis of iron overload of histochemical and chemical iron in the liver of control subjects A. WEINFELD, P. LUNDIN, and O. LUNDVALL

Effects of two oral iron preparations on results of the benzidine test for occult blood in stools J. D. CuMMING and H. G. PERCIVAL

Glucose-6-phosphate dehydrogenase deficiency in Chinese H. C. LAI, Michael P. Y. LAI, and KeVIN S. N. LEUNG

Extreme neutropenia in glandular fever HUGH G. PENMAN

Seronegative glandular fever HUGH G. PENMAN

Effect of injected heparin on platelet levels in man M. G. DAVEY and HARRY LANDER

Argentaffin and non-argentaffin carcinoid tumours of the appendix F. E. DISCHE
Consistency in the histological diagnosis of epithelial abnormalities of the cervix uteri J. COCKER, H. FOX and F. A. LANGLEY

Morphogenesis of testicular tumours J. C. CROOK Sensitivity of pencillinase-forming strains of Staphylococcus aureus and of their penicillinase-negative variants to cephaloridine, cephalothin, methicillin and benzylpenicillin J. H. HEWITT and M. T. PARKER

Effect of light on the Lactobacillus casei microbiological assay BARBARA B. ANDERSON and JEAN D. COWAN

Absorption of antibiotics during peritoneal dialysis in patients with renal failure A. C. BUCK and SIMON L. COHEN

Classification of Staphylococcus albus strains isolated from the urinary tract R. G. MITCHELL

Epidemiological aspects of Proteus infections with particular reference to phage typing DIANA R. FRANCE and N. P. MARKHAM

Drug sensitivity of Proteus species C. T. HUANG and GRACE CHOU

\section{Technical methods}

Demonstration of Paneth cell granules using Naphthalene Black DIANA BOWER and c. G. CHADWIN

A fluorescent technique for demonstrating treponemes in films made from suspected chancres M. F. GARNER and J. H. ROBSON

Recovery of human foetal liver cells after storage in liquid nitrogen A. J. ZUCKERMAN, H. E. M. KAY, and A. B. HOCKLEY

Rapid method for the estimation of plasma haemoglobin levels C. M. CRIPPS

Specific determination of plasma and urinary lactose P. A. TOSELAND

A simple device for microdialysis A. A. CoDD

Letter to the Editor

Journal of Medical Microbiology

Postgraduate education

Book reviews

Copies are still available and may be obtained from the PUBLISHING MANAGER BRITISH MEDICAL ASSOCIATION, TAVISTOCK SQUARE, W.C.1, price 18s. 6D. 